\title{
Ethnologies
}

\section{Exhibiting Music in a Sound Community}

\section{Jeff Todd Titon}

Volume 37, numéro 1, 2015

Exposer les paysages sonores

Exhibiting Soundscapes

URI : https://id.erudit.org/iderudit/1039654ar

DOI : https://doi.org/10.7202/1039654ar

Aller au sommaire du numéro

\section{Éditeur(s)}

Association Canadienne d'Ethnologie et de Folklore

ISSN

1481-5974 (imprimé)

1708-0401 (numérique)

Découvrir la revue

Citer cet article

Titon, J. T. (2015). Exhibiting Music in a Sound Community. Ethnologies, 37(1), 23-41. https://doi.org/10.7202/1039654ar

\section{Résumé de l'article}

Exposer la musique dans une communauté introduit la présence et le potentiel d'une rationalité écologique. Deux êtres ou plus, présents l'un à l'autre dans le son, résonnent à la même fréquence l'un et l'autre et constituent une saine communauté de son. La coprésence sonore est intersubjective et relationnelle, sur le mode du savoir réciproque et évocateur de sujet à sujet, plutôt que sur le mode du savoir manipulateur, asymétrique, de sujet à objet. Dans une saine communauté de son, la musique est communicative, aussi naturelle que le fait de respirer ; elle s'échange librement, elle invite à la participation, elle renforce et nourrit les individus et les communautés. Une saine communauté de son fait preuve d'une économie saine, juste, participative et égalitaire. Richesse et pouvoir sont largement répartis et partagés, et entretenus par la main visible de la gestion démocratique. Une économie saine s'enracine dans une écologie saine où les échanges sont basés sur des signaux honnêtes qui invitent à la réciprocité et à la confiance. Dans une saine écologie de son, l'être sensé et le savoir sûr conduisent à la production intelligente du son, qui est coopérative, mutuellement bénéfique et juste.
Ce document est protégé par la loi sur le droit d'auteur. L'utilisation des services d’Érudit (y compris la reproduction) est assujettie à sa politique d'utilisation que vous pouvez consulter en ligne.

https://apropos.erudit.org/fr/usagers/politique-dutilisation/ 


\section{Exhibiting Music in A Sound Community}

\section{Jeff Todd Titon}

Brown University

In this presentation I offer you the outlines of a portrait of a sound community, characterized by a sound economy, and enveloped in a sound ecological rationality ${ }^{1}$. That is, I will explore some possibilities of a community, economy, and ecology erected on sound principles. By a sound community I mean a community established and maintained by acoustic communication. I also mean a reliable, healthy, and resilient community. And by community I mean a community of all living beings, not just humans. In our post-humanist world where the approaching environmental catastrophe moves responsible people to become stewards of our planet, we are just coming to understand that sound communities include all life, including plants as well as animals. Our so-called developed societies might have learned that from indigenous communities, had not our scientists dismissed their thought systems as animistic. But now plant intelligence scientists such as Monica Gagliano are reporting positive results in their experiments on acoustic communication among plants (Gagliano, 2012: 789-796).

The subject of this conference is "Exhibiting Music," while the subject of the October gathering in Edmonton is "Exhibiting Sound." This interchangeability of subjects is appropriate to the current moment, when musicology, ethnomusicology, and ecomusicology converge on sound and blur distinctions between sound and music. Forty, even twenty years ago one could say without much hesitation that sound studies and music studies pursued different ends. One could say that sound was a fact of nature whereas music was an expression of culture. But, as the dichotomy blurs between

1. Keynote Address, CSTM Conference, Sydney, N.S., Canada, June 17, 2015. I am grateful to my hosts at Cape Breton University, and especially to Marcia Ostashewski for her invitation to keynote this conference and the pre-conference as well. I cite my earlier writing often because this essay describes ideas unfolding over a period of many years. 
nature and culture, so with sound and music. Both sound and music exist as natural facts, and both exist as Western cultural categories. Questions such as the role of music in human evolution remained opaque for more than a century (Brown et al., 2001). I believe they will open to a different and broader formulation, namely, What is the role of sound in the evolution of life on planet earth? Music is a part of that evolution, but only a part of it.

Composers in the twentieth century understood sound before musicologists did. John Cage understood that music is only one kind of sound, and that sound is an interruption of silence. Cage also wrote that every idea he ever had that was worth its salt, he could find expressed one hundred years earlier, by Henry David Thoreau (Cage, 2010: 18). It was Thoreau who wrote in 1838 that sound was but a bubble on the surface of silence (Thoreau, 1981: 61-62). It was Thoreau who found music in the sounds of the natural world. It was Thoreau who in 1842 cautioned music historians that they had no subject when he wrote, "Most lecturers preface their discourses on music with a history of music, but [they might] as well introduce an essay on virtue with a history of virtue. As if the possible combinations of sound, the last wind that sighed, or melody that waked the wood, had any history other than a perceptive ear might hear in the least and latest sound of nature!" (Thoreau, 1981: 369). And so when I speak about exhibiting music in a sound community, I mean to trouble the distinction between music and sound even further.

This project has been growing out of my work in music and sustainability during the past decade. Here is a broad summary of the position that I will be placing before you. You may find some of it agreeable, some of it disagreeable, and some of it obscure; but I ask you to bear with me, hoping it will clarify. Here is the argument in outline thus far: Exhibiting sound announces the presence and potential of a community of living beings. Two or more beings co-present to each other in sound resonate at the same frequency with one another and comprise a sound community. Copresence in sound is intersubjective and relational, a subject-to-subject resonant and reciprocal way of knowing, rather than a subject-to-object, asymmetrical and manipulative knowledge. In a sound community music is communicative and as natural as breathing. In a sound community, music is participatory and exchanged freely, strengthening and sustaining individuals and communities. A sound community exhibits a sound economy. Contrast it with an unsound economy, which is organized hierarchically, where wealth and power are unevenly distributed, where consumption is valued while production is slighted, and all the while the economy is regulated 
for the benefit of the wealthy and the exploitation of everyone else. In an unsound economy, economic injustice is rationalized by an invisible hand that promises works for the public good, while technological innovation promises an eventual solution for all economic problems. That is the socalled economic rationality that governs our unsound economy today. A sound economy, on the contrary, is just, participatory and egalitarian. Wealth and power are widely distributed and shared, and maintained through the visible hand of democratic management. A sound economy is based in a sound ecology. Contrast it with an unsound ecology, in which deceptive communication invites fear, anxiety, and competition. An unsound ecology is an entitlement ecology, where resources are regarded as ecosystem services. On the contrary, in a sound ecology exchanges are based in honest signals that invite reciprocity and trust. In a sound ecological rationality, sound being and sound knowing lead to sound action, which is cooperative, mutually beneficial, and ecologically just.

I make no apology for framing my presentation within Western ways of being, knowing, and doing, even though indigenous worldviews offer insights into these issues. My colleague Steven Feld traveled to Papua New Guinea and found an acoustemology among the native Kaluli there, while I learned a great deal about sound in the natural and human worlds from Passamaquoddy elder Wayne Newell (Feld, 1996: 91-135). But one needn't travel so far outside Western philosophy to find kindred spirits, such as Gilbert White, Aldo Leopold, Henry David Thoreau, Mary Treat, and Michael Soulé, or kindred traditions such as phenomenology and conservation biology. Indeed, within Western science alternatives are increasingly gaining traction: social selection is challenging selfish gene theory, while ecological economics combats neoclassical economics, and conservation biology conceives of nature as an integrated whole rather than as a resource for ecosystem services (Roughgarden, 2010; Daly and Farley, 2010). Neuroscientists have discovered that a bird, on hearing the song of its mate, releases serotonin in its brain, just as humans do when listening to music they love (Earp and Maney, 2012). My argument, which is based in but not limited to the ontology and epistemology of sound, opposes the contemporary unsustainable economic rationality, which I believe is death, and instead advocates a sustainable ecological rationality, which I believe is life. Here I would like to acknowledge the influence of the Mexican political ecologist and environmental epistemologist Enrique Leff, in helping me connect my ideas concerning sound being, knowing, and doing to an emerging ecological rationality. As I try to make this sound argument in 
the public sphere of the Western world, I want to make it in terms more persuasive to people outside academia. To them, a Kaluli acoustemology must remain at best a beautiful metaphor. I am concerned to help bring about a future based in a sound ecomusicology, not in our current unsound neoliberal political economy. Let us see how sound may help to do that.

I begin my argument by claiming that sound announces presence. Sound says "here I am." It says it to the sounder and to any other creature who may feel the sounder's vibrating resonance in its body, whether through an ear or other means of reception. Sounding locates a being in space and time. This concept, presence, is a cornerstone of the metaphysics of being, whether in Western thought or Eastern philosophy or indigenous worldviews. We speak of the presence of others and of ourselves; we speak of sensing a spiritual presence. Presence means "being there." Fieldwork privileges presence; we ethnomusicologists understand the importance of being there. In privileging presence we privilege experience, for presence must be felt or experienced. Affect is the experience of a powerful presence; we associate it with ritual, with ceremony, with art, with feelings of expansion such as love, and contraction such as opposition.

Unquestionably the most powerful contemporary critique of sound and presence was mounted by Jacques Derrida, in his Of Grammatology and elsewhere, in which he attempted to deconstruct what he termed "the metaphysics of presence" in Western thought, an intellectual tradition that came to him chiefly via Continental philosophy, particularly phenomenology (Derrida, 2013). Sound in presence had been a minor subject there. Husserl and Heidegger made reference to it, Husserl in particular linking music with inner time (Husserl, 1991). Inner time refers to how humans experience time; how time is present to consciousness. The keystone of the metaphysics of presence, Derrida felt, was a mistaken belief in the priority of speech. Sound, of course, is the medium for speech. Derrida pointed out that Western thought regards writing to be derived from speech, and in so doing assigns an authenticity of presence to the spoken word that writing does not possess. Derrida sought to deconstruct dichotomies in Western thought such as positive/negative, presence/absence, and speech/writing. He felt that these mistaken dichotomies privileged one term over the other in a hierarchy of thought: thus positive was regarded as preferable to negative, presence to absence, and speech to writing. I agree with Derrida that negativity, absence, and writing are preferable in certain circumstances, and I agree that a metaphysics that privileges presence is not intrinsically superior or somehow more authentic. My concern with 
presence sidesteps the issue of authenticity and hierarchy; I simply assert that presence arises from the reception of a sensory signal-in this case, sound that emerges from the vibration of a living creature; and I do not claim it is primary, merely that it exists. In fact, sound usually falls victim to sight in a Western hierarchy of the senses. It has become a scholarly truism that our society gives preference to the visual; we say "I see" to mean "I understand," and we use phrases like "cast light on it," and words like "insight" to mean knowledge. I am one with Derrida here: let us have a level sensory playing field. One could discuss presence in terms of any and all kinds of sensory experience: sight, sound, smell, taste, touch, and so on. I do not claim superiority for sound; I merely want to investigate its consequences.

Derrida went on to assert that presence was not, as Western metaphysics understood it, received as a direct and unmediated expression; instead, everything received by human consciousness is received as a sign or indicator, and there is no such thing as pure unmediated experience. Indeed, for Derrida humans have no direct, unmediated access to consciousness or its objects; we cannot think, or process experience, without signs. Again, I have no quarrel with Derrida; sound signals are received as signs in human consciousness and in non-humans in what we may term awareness, if not consciousness. If Derrida claims that acoustic signals as signs always mediate human experience by lodging in consciousness as thought, then we do have a quarrel, because humans do experience certain acoustic signals, resonate with them, and react without conscious thought. An obvious example occurs when we hear a loud noise and flinch in a flight response. I would give sound signals priority in this sense, but it is only a temporal priority, not a philosophical one. This is what Thoreau meant when he wrote in the "Sounds" chapter of Walden that sound speaks in a language without metaphor (Thoreau, 1971: 111). Needless to say, we do not yet understand what, if anything, might correspond to language and thought in non-human species; but we do know that acoustic alarm calls for trigger fight or flight responses. Robert Frost in 1915 wrote of tones "living in the cave of the mouth," that were there prior to language and remain there to shape poetic utterance if we would but listen to them (Frost, 2014: 355). In short, I do not wish to claim a special authenticity for acoustic communication and sound ways of being in the world; I wish only to propose it as a way of imagining and bringing about a world worth wanting, grounded in a way of being and knowing and doing that I suggest we with a sensitivity to sound have a responsibility for sharing. 
When you sing in the shower you are, among other things, announcing your presence to yourself. When you hold that music in your awareness you are experiencing it as presence. Now the word exhibit, from the Latin "ex" or out, plus the verb "habere," to hold, contains the idea of holding something out. In middle English it acquired the connotation of holding something out for consideration in a court of law, as the court considers "exhibit A" for the prosecution or "exhibit B" for the defense. So, in its root sense, to exhibit sound or music means to hold it out for consideration. My point here is that in addition to our thinking about curating and exhibiting sound for others in museums, concerts, and so forth, we may think about exhibiting sound in the sense of announcing presence. Every time a creature holds out sound present in its awareness, we have an exhibit of sound. Let us understand exhibiting music as a part of a larger acoustic signaling more generally, which is to say that any sending and receiving of music is an exhibition of sound.

In thinking about how sound signals presence, it is important to bear in mind that it signals presence both to the creature itself and to other creatures. My first proposition was that sound signals presence. My second is that two beings present to each other constitute co-presence. Sounding is one of several means of co-presence. Touching is another. But unlike other sensory signals of co-presence, sounding involves vibrating at the same frequency, the basis for a sound community. In human music, of course, copresence enables coordination so that people may sing and play together. Whether it is a string quartet or a string band, making music together is enabled by co-presence, when two or more people are present to each other. Learning to make music well with others, as you know, means learning to hear not only one's own sound presence but also others' sounding presences. Beginning musicians only have ears for themselves.

Sounding co-presence, of course, is a more general phenomenon of the living world. It needn't mean that both creatures emit sounds. The bee dance to tell hivemates the location of a honey source is well known; but that information is indicated more reliably by the dance-accompanying buzzing sounds they emit at low frequencies (Wenner, 1964: 116-124). A bird signals presence to its mate with its song. The mate must be able to recognize in the song, which to humans sounds like every bird's species song, the individual bird that is its mate. Birds must hear more in these songs than we humans do. We may begin to hear a little more in a bird's song if we slow its time down. Listen, for example, to my recording of a hermit thrush on Little Deer Isle, Maine, at normal speed and then slowed 
down to half speed and lowered an octave. ${ }^{2}$

I will mention another phenomenon of bird song, the flight call, in connection with a recent publication in the CSTM journal, MUSICultures. It contains a short story in which a young man standing at the edge of a spruce forest hears and records a cry of a bird unknown to him. Then the bird flies away. When he listens to Audubon Society recordings to try to identify the bird, he learns its species name and that he was hearing its flight call. The young man mistakenly thinks a flight call is an alarm call, and that the bird was alarmed by his intrusive presence. Eventually he learns that a flight call is something else: it is an announcement of presence that birds make to let others know where they are, so as to keep the flock together. Keeping the flock together is a figure for community in co-presence. The implications for the human community should be plain. Less plain, perhaps, is a suggestion about the larger community of all life.

The term co-presence was introduced to sociocultural analysis by Erving Goffman in his 1967 book, Interaction Ritual. The meaning of co-presence is suggested by the book's subtitle, "Essays in Face-to-Face Behavior." Drawing on his earlier work, The Presentation of Self in Everyday Life, Goffman insists that co-presence does not occur when two people merely inhabit contiguous space; they must, as it were, present their selves to each other. In other words, they must communicate (Goffman, 1959; Goffman, 1982). More recently, some sociologists have extended co-presence to include virtual presence, to reference communication, by means of technology, among presenting selves not necessarily in the same location. In this sense, people can be co-present to each other over the Internet (Zhao, 2012: 445-455). Communication among two or more actors, present either physically or at a distance, is key in co-presence.

Co-presence may soon enter popular discourse. Last winter Google was rumored to be working on an app called Copresence. The tech journalists thought it would be an app like Apple's AirDrop to enable communication between an Android device and a PC, or to enable cross-platform communication among Apple and Android devices, for file exchange and who knows what else. Imagine a cross-platform conversation that would bring together Google's Voice Assistant and Apple's Siri. What would they say to each other?

2. Both audio files are available in mp3 format at: http://www.ethnologies.ulaval. ca/wp-content/uploads/2017/02/Hermit_Thrush_Songs___2013_-_normal_ converted.mp3 (normal speed) and http://www.ethnologies.ulaval.ca/wp-content/ uploads/2017/02/Hermit-Thrush-Songs-2013-slow.mp3 (slow). 
And so my third proposition is that a sounding co-presence among two or more actors may lead to a community. The word community is as ubiquitous in social analysis as it is imprecise. Perhaps its vagueness is an advantage, for it is easier to assent to an ethnomusicologist's use of the term community when we can draw from a multiplicity of meanings and find one that is agreeable. In the twentieth century, sociologists refined the concept, contrasting a community in which a person feels a sense of identity and belonging, to mass society where a person feels anonymous and alone. A community can be a socially organized group, or it can be a subculture, such as the academic community. It can be an organized geographical unit, or a moral community such as the pro-choice advocates or the peace movement. It can be merely an affinity group, such as musicians, or bridge players, who get together on occasion but may not have much else in common although they may sense they do. Sociologists also speak of intentional communities, where people choose to join or leave; and of communities that people are born into and cannot escape from. The key idea is that members of a community are related to one another in one or more ways; it is not a random collection but rather involves a shared or interdependent relationship based in a communicating co-presence among two or more actors.

Needless to say, exhibiting sound is but one of many ways of communicating co-presence within a community. Yet it is an important way, and we may say that its importance lies in its particular association with the actors that produce the sounds. Sound communication differs from written communication in obvious and not so obvious ways. As sounds are vibrations with a temporal frequency, when the vibrations cease, so do the sounds. Vibrations give a tactile experience to sounds. Sounds travel through a medium such as air or water or solids, and they pick up something of the character of that medium. Thoreau wrote perceptively in 1851 that the sound of a church bell heard at a distance through the forest was unlike the sound of a bell heard nearby; for the vibrations coming through the forest assume to some extent the echo of the wood and the leaves and the earth and the air before they reach the ear (Thoreau, 1992: 142-143). Murray Schafer often tells audiences that although humans have eyelids, "there is no silence for the living. We have no ear lids" (Schafer, 2006).

Musical communication, in this regard, is but a part of the larger category of sound communication, something we regard as a human art. I need not go into detail concerning how and what music communicates; music scholars do not need reminding that music establishes identities, 
and that it brings communities into being, and maintains them. That is what a music culture is all about. Ecosystems are characterized by producers and consumers, with a flow of energy throughout; the same can be said of music cultures, which have their own populations and communities of producers and consumers, with music flowing throughout (Titon, 1984: 9; Titon, 2015: 177-178).

I think we may be able to say certain things about sound communities, based partly on what we know about human music-making, and about that musicking within the context of animal sound communication more generally. I am sure you all have experienced peak music-making experiences, when the music seems to be making you rather than the reverse. The classic phenomenological discussion of this is in an essay by Alfred Schütz, where he discusses its intersubjective nature, particularly in reference to string quartet playing. People making music together relate to one another as subjects, not objects. Tellingly, Schütz terms them "coperformers" (Schütz, 1951:76). Schütz invokes Jean-Paul Sartre's concept of "le regard" characterized by "looking at the other and being looked at by the other" and translates it into sound communication when he calls it a "tuning in relationship upon which all communication is founded." He continues: "It is precisely this mutual tuning relationship by which the 'I' and the 'Thou' are experienced by both participants as a 'We' in vivid presence" (Ibid., 79). Here, Schütz is describing the experience of co-presence as a subject-to-subject, relational way of being, knowing, and doing, rather than an asymmetrical subject-to-object, manipulative way. In other words, he is describing people in a relational ontology, epistemology, and activity.

I wrote about this kind of experience about 20 years ago, taking the musical jam session as a model for this intersubjective experience, and asked what it would be to found a philosophy on intersubjective musical being and knowing, rather than taking the objective interpretation of a text as the paradigm case for understanding (Titon 1996). This presentation, and my recent work on sound, Thoreau's journals, ecomusicology, climate change, and my appeal for a sound commons (Titon, 2012) all are movements toward founding an ontology and epistemology on sound being and sound knowing. About 15 years ago, in my Introduction to a book on Kentucky fiddle tunes, I further described the jam session as a model of intersubjective social behavior that can move from the musical arena of being and knowing to the political arena of doing participatory democracy in other aspects of life (Titon, 2001). I want to discuss this all now in terms of an ecological 
rationality. But moving to overturn an economic rationality and replace it with an ecological one is not as simple conceptually as it may at first seem. To most friends of music who also are friends of the earth, the ecological rationality of sustainability on a green planet seems unalterably opposed to the economic rationality of global market capitalism. When I began exploring a means to get off the path of economic rationality and onto an ecological one, I foresaw only the practical problem of convincing people to live more lightly and harmoniously on the earth. Like most friends of the earth whose understanding of ecology was formed in the environmental movement of the 1960s and 1970s, I believed that nature left to its own devices moved through a succession of stages to a well-integrated whole, a stable but dynamic equilibrium state summed up in the oft-used phrase, the balance of nature. Considering music within an ecological context meant thinking about music cultures as ecological systems (Titon, 1984:9).

But when I came again in the new millennium to explore music cultures as sustainable ecological systems, I found that the ecologists had shifted paradigms. The balance of nature had given way to an image of nature characterized by constant change, by disturbances from within and forces from without, with resultant shifts from one regime to another: a succession of temporary equilibria, one after another without apparent rhyme or reason, and certainly no progression to a balanced, well-integrated, and sustainable whole. If music cultures behaved as ecological systems, sustainability now seemed a difficult if not impossible goal. And so I began to explore resilience strategies to enable sustainability by means of continuity and integrity, the topic of my pre-conference keynote a few days ago. ${ }^{3}$

Yet in moving from music sustainability to sound sustainability, and from music communication to sound communication, a new area, namely animal sound communication, opened to me. It now made sense to explore human music within the larger context of animal behavior, so a few years ago I began to undertake that study. How might I understand sounding presence, and co-presence, and a sound community within an ecological context centered in animal sound communication? What might one learn about that from studies of animal behavior consequent on the cries of monkeys, the chirps of squirrels, and the songs of birds and whales and dolphins? What was the economy of this sound exchange of information among animals, and would it be possible to erect upon it an ecological rationality for sound human behavior that would stand in opposition to

3. "Caring with People Making Music," keynote address, CSTM Pre-Conference on Curating Ethnomusicology, Cape Breton University, June 15, 2015. 
neoliberalism's prevailing economic rationality and consequent injustice?

Here, I was prepared to encounter the paradigm shift from a balance of nature to a succession of regime shifts in the face of disturbances; and I did. A postmodern ecological paradigm did not cause me to lament, as it caused Donald Worster, the most accomplished historian of ecological thought, to do (Worster, 1994a, 1994b). But I was unprepared to find the incestuous conceptual relationship between these two worlds, economy and ecology. Throughout the history of Western thought, ideas about nature and ideas about trade and the exchange of goods and services have seldom been in opposition to one another; in fact, they usually move in tandem. Ecology and economy have been intertwined from the outset, even in having the same Greek root origin, oikos, meaning household. In the 1860s Ernst Haeckel coined the term "ecology" to refer to what writers of the Enlightenment had previously called nature's economy, or earth's household (White, 2013 [1789]). In that one phrase, nature's economy, the economic and natural worlds are combined into a portrait of nature as an efficiently operating system of exchanges. Darwin, a gentleman-amateur scientist, used the term "nature's economy"; but it fell out of fashion in the world of twentieth-century technoscience. Nevertheless, its economic metaphors continue in ecosystem ecology, which still categorizes organisms as producers and consumers of energy. It is not accidental that the two most powerful discourses of sustainability arose from both economics and from ecology; yet in economics sustainability chiefly means sustainable development, while in ecology it means conservation management. The history of science, which is to say the history of how humans in the West explain nature, is tied inextricably to economics. I do not simply mean a tie to the economic patronage that supports science, or a link to the notion that truth in early modern science owed more to a gentleman scientist's wealth and social standing than to the merit of his argument, although both of those propositions are accurate (Shapin, 1994). I mean a link in epistemology, or ways of knowing, as for example the fact that the emergence of an experimental, mathematics-based science of nature in fourteenth-century Europe came at the exact moment when money began to circulate in earnest among the priests and educated classes, and so after they began to count money natural philosophers began to measure things. (Kaye 2000). It was then that mechanical astronomical clocks first appeared in Europe.

In Renaissance Europe, trade and the circulation of money in the body politic were regularly likened to the circulation of blood in the physical body. 
Economists no less than philosophers during the Enlightenment regularly wrote of human nature; Adam Smith famously wrote that human beings have a "natural propensity" to "truck, barter, and exchange," and that "it is not from the benevolence of the butcher, the brewer, or the baker that we expect our dinner, but with regard to their self-interest" (Smith, 1776, Bk. I, chaps. 2 and 3). John Stuart Mill wrote that economics was that subject concerned with man "solely as a being who desires to possess wealth, and who is capable of judging the comparative efficacy of means for obtaining that end" (Mill, 1963 [1844], IV: 321). Thus homo economicus. Economic man is the fundamental building block of mainstream Western economic rationality, just as small particles are in physics. Among neoclassical economists of the $19^{\text {th }}$ century, Darwin's idea of a struggle for existence in nature became a rationale for economic competition and a justification for income inequality. Today, of course, this social Darwinism justifies the neo-liberal economics which, beginning in the Reagan-Thatcher era, overturned liberal Keynesian ideas about government's role in managing economies. Income inequality is now regarded by conservative politicians as the natural outcome of a competitive struggle for economic supremacy and material wealth. The most consequential result of neo-liberal policy is social, economic, and environmental injustice; but also pertinent is the way social Darwinism rationalizes the ideas of neo-liberalism, another instance of economics bedding down with ecology. It seems impossible to separate the two in Western thought. My point is that while nature may be an external reality, European constructions of nature reflect and are influenced by constructions of economics, and vice-versa, in any given historical period.

When I turned to the study of animal sound communication, I found that contemporary behavioral ecologists operated with the same ideas as the neo-liberal economists, back-translated to the ecological realm from the economic (Bradbury and Vehrencamp, 2011). Here, the governing idea was that animals communicated with each other not so much to convey information as to manipulate the behavior of others. Animals were engaged in a struggle for existence, termed fitness-the word comes from the Darwinian "survival of the fittest." Behavioral ecology was neo-Darwinian in combining fitness with selfish gene theory, the idea popularized by Richard Dawkins in the 1970s that animal behavior is determined by a genetically programmed drive to pass along one's genes to the next generation. To maximize its chances, an animal always acts selfishly and competes with other animals for the best territory, the best mates, 
dominance over others, and a long life with as many offspring as possible. It was Dawkins who proposed that manipulation of others' behavior was the purpose of animal communication, with sound as the paradigm case. Dawkins distinguished between honest and dishonest signals. A dishonest signal was designed to mislead the other animal into thinking that the sender was bigger, stronger, braver, in a different location than it was, and so forth. To Dawkins and his followers, the animal world is filled with dishonest and deceptive sound communicators intent on manipulating friend and foe alike (Dawkins and Krebs ,1978). Most behavioral ecologists studying animal communication from the late 1970s onward have based their research in this hypothesis, coupling it to cost-benefit game theory in which survival and passing on one's genetic inheritance was the object of the game of life for animals (Alcock 2013: 102-136). It is hard not to notice the parallels between selfish gene theory and global corporate capitalism, with rewards such as dominance, territory, and trophy wives for the male CEOs. The communicative efforts of some corporations, such as Monsanto's attempts at greenwashing, are dishonest signals meant to manipulate a gullible public.

The neo-Darwinian behavioral ecologists realized that objections to selfish gene theory would be raised from scientists who would point out instances of animal benevolence. Dawkins and his followers attempted to control in advance the discourse of the dissenters by raising objections themselves, then answering them. They advanced a theory to account for apparent altruism in the animal kingdom, such as parental care for young, or alarm cries warning others of danger. Altruism, they argued, wasn't really disinterested; it wasn't even altruism. Supposed instances of animal altruism always were directed at members of the animal's kin group, that is, those that shared in the animal's genetic inheritance. The neo-Darwinists thus explained apparently unselfish behavior by means of selfish gene theory (Alcock, 2013: 15-42).

Within animal sound communication, of course, we have presence, co-presence, and community. Animals announce their presence in various ways; sound is one of them. The jury is out on whether non-humans possess what we call consciousness, but it appears that they possess awareness, if not self-awareness (Smith and Mitchell, 2012). With awareness they are present to each other, that is, co-present, as in the familiar act of a bird singing to mark territory, attract a mate, alarm its neighbors, threaten a potential rival, or keep the flock together. Community is one of the key concepts of ecosystem ecology; it refers to the interactions among 
populations of different species inhabiting a given area. In other words, groups of individuals of the same species comprise populations, while populations of different species form communities, such as flocks of nuthatches and chickadees that forage together in winter. Communities interacting are characteristic of ecosystems. Unquestionably, at every level (population, community, ecosystem) animal sound communication initiates competitive behavior compatible with selfish gene theory; also, sounds may also inadvertently reveal the location of prey to predators. However, it is equally true that at every level sound communication initiates cooperative behavior essential for individual and group survival; and while sounds do reveal prey to predators, they also warn neighbors of predators. In that regard, experiments with the alarm calls of vervet monkeys were the object of much attention some years ago when scientists learned they had four distinct kinds of sounds signaling alarm, each for a different kind of predator, and each requiring a different type of avoidance behavior. The monkey wasn't just sounding a cry of fear but specifying the danger and what to do in response. The alarm sound for a leopard instructs the monkey to run up a tree; for an eagle, to look up in the sky; for a snake, to look down on the ground. Since then, it's been learned that other animals also have predator-specific alarm sounds (Bradbury and Vehrencamp, 2011: 578). While this sound communication can be interpreted as behavior to manipulate others and maximize group fitness, it can also be understood as socially cooperative, transmitting information about the type of predator in order to maintain the population group. Gradually, scientists are finding evidence that selfish gene theory may not have the full explanatory power it has been granted. They are finding evidence of social selection, the idea that mating partners are chosen not only the basis of good genes but also in demonstrating potential for cooperative behavior needed in child rearing (Roughgarden, 2010). They are finding that animal sound communication consists chiefly of honest signals meant to transmit information, not dishonest signals intended to manipulate outcomes. Although selfish gene theory remains the dominant paradigm, there is enough contrary evidence for me to believe that an alternative ecological rationality, one based in sociality, negotiation, and cooperation is not merely an ideal but is based in fact. ${ }^{4}$ It is this ecological rationality that I wish to bring to bear in the project of a sound community, for it may then be possible to erect on its foundation a more just economy.

4. From a scientific standpoint one cannot reject selfish gene theory or limit its scope merely because one finds it abhorrent. It can be shown inadequate only if it does not explain a pattern of facts. 
A sound community's expression of a just economy serves as an alternative to global corporate capitalism. Many of its features are already in action on a small scale, and many more are under discussion. They should be familiar to you in catch phrases like local exchanges, local food, local goods, and even local music and dance; land trusts, renewable local energy, the so-called sharing economy, creative commons, and so forth. The greater power of the personal and local is indeed reflected in ecosystem ecology, where local conditions are more important to everyday life than distant ones. I do not have time to explore more ramifications of a sound economy here, so I must instead refer you to my research blog on music and sustainability, particularly to entries concerning ecological economics, gift exchanges, cultural and intellectual property rights, heritage tourism, and the creative economy (Titon, 2008-present).

In conclusion, I put forth for your consideration an idea for a managed sound commons in which every creature is free to communicate in its acoustic niche. Soundscape ecologists have amassed convincing evidence to show that species adapt so as to communicate with each other in particular sound niches according to frequency, duration, timbre, volume, time of day or night, and so forth, in order that their sounds should not be much interfered with (Pijanowski et al, 2011: 202-216). Human sounds such as airplane flyovers, naval sonar, and shipping noise interfere with intraspecies communication. Birds have been observed to adjust their songs to anthropogenic (i.e., human-caused) noise interference; the pitch registers of birdsong near highways was found to be higher than that of the same species living in forests in the same region (Gough et al, 2014). In far northern Canada, helicopter noise from mining company explorations confuses caribou and upsets their migrating routes. Not only does the soundscape pollution impact the caribou, but also human groups such as the Innu whose traditional lifeways (food, clothing, shelter) were fully dependent on caribou hunting - a practice they attempt to continue still, to maintain their culture, even though these former nomads now are settled in villages. It's all connected: music to sound, human to animal, culture to nature. Just as the exhibition of sound is enveloped by environment, so is culture, by both the human-built and natural environments. A sound commons, where all living beings enjoy a commonwealth of sound, embodies the principle of sound equity, encouraging free and open sound communication, and playing its important part in environmental, musical, and cultural sustainability (Titon, 2012). A commons, or res communes, according to Roman law, was a thing (res) that by its nature is incapable of 
being "captured" and thereby possessed. A commons, then, is not owned by any individual; it is shared. Roman law, which is the basis of Euro-American law, gave as its usual examples of res communes the air mantle and the ocean (Rose 2003). I submit that the same is true of the soundscape: it belongs to the whales, birds and crickets as much as to you and me.

A sound commons available to all and owned by none is an example of a sound community, a sound economy, and a sound ecology. To end, I repeat the broad outline of the position I am putting before you. Exhibiting sound announces the presence and potential of a community of living beings. Two or more beings co-present to each other in sound comprise a sound community. Co-presence in sound is intersubjective and relational, a subject-to-subject relational and reciprocal way of knowing, rather than a subject-to-object, asymmetrical and manipulative knowledge. In a sound community music is communicative and as natural as breathing. In a sound community, music is participatory and exchanged freely, strengthening and sustaining individuals and communities. A sound community exhibits a sound economy. Contrast it with an unsound economy, which is organized hierarchically, where wealth and power are unevenly distributed, where consumption is valued while production is slighted, and all the while the economy is regulated for the benefit of the wealthy and the exploitation of everyone else. In an unsound economy, economic injustice is rationalized by an invisible hand that promises works for the public good, while technological innovation promises an eventual solution for all economic problems. That is the so-called economic rationality that governs our unsound economy today. A sound economy, on the contrary, is just, participatory and egalitarian. Wealth and power are widely distributed and shared, and maintained through the visible hand of democratic management. A sound economy is based in a sound ecology. Contrast it with an unsound ecology, in which deceptive communication invites fear, anxiety, and competition. An unsound ecology is an entitlement ecology, where resources are regarded as ecosystem services. On the contrary, in a sound ecology the exchanges are based in honest signals that invite reciprocity and trust. In a sound ecology, sound being and sound knowing lead to sound action, which is cooperative, mutually beneficial, and ecologically just. 


\section{References}

Alcock, John. 2013. Animal Behavior: An Evolutionary Approach. 10 ${ }^{\text {th }}$ ed. Sunderland, MA: Sinauer Associates.

Bradbury, Jack, and Sandra Vehrencamp. 2011. Principles of Animal Communication. $2^{\text {nd }}$ ed. Sinauer Associates.

Brown, Steven, Björn Merker, Christina Wallin, and Nils L. Wallin, eds. 2001. The Origins of Music. Cambridge, MA: MIT Press.

Cage, John. 2010 [1973]. M: Writings 1967-1972. Middletown, CT: Wesleyan University Press.

Daly, Herman E., and John Farley. 2010. Ecological Economics. $2^{\text {nd }}$ ed. Washington, DC: Island Press.

Dawkins, Richard, and John H. Krebs. 1978. "Animal Signals: Information or Manipulation?" in Behavioural Ecology: an Evolutionary Approach, ed. J. R. Krebs and N. B. Davies: 282-309. Sunderland, MA: Sinauer Associates.

Derrida, Jacques. 2013. Of Grammatology. Corrected edition. Baltimore, MD: Johns Hopkins University Press.

Earp, Sarah E., and Donna L. Maney. 2012. "Birdsong: Is It Music to their Ears?" Frontiers in Evolutionary Neuroscience 4: 1-10.

Feld, Steven. 1996. "Waterfalls of Song: An Acoustemology of Place Resounding in Bosavi, Papua New Guinea." In Senses of Place, ed. Steven Feld and Keith Basso: 91-135. Santa Fe, NM: School of American Research Press.

Frost, Robert. 2014. The Letters of Robert Frost, Vol. 1: 1886-1920. Donald Sheehy, Mark Richardson, and Robert Faggen, eds. Cambridge, MA: Harvard University Press.

Gagliano, Monica. 2012. "Green Symphonies: a call for studies on acoustic communication in plants." Behavioral Ecology 27(4): 789-796.

Goffman, Erving. 1959. The Presentation of Self in Everyday Life. Garden City, NY: Anchor Books.

- 1982 [1967]. Interaction Ritual: Essays in Face-to-Face Behavior. New York: Pantheon.

Gough, Danielle C., Daniel J. Mennill, and Erica Noll. 2014. "Singing Seaside: Pacific Wrens Change their Song in the Presence of Natural and Anthropogenic Noise." Wilson Journal of Ornithology 126(2): 269-278.

Husserl, Edmund. 1991. On the Phenomenology of the Consciousness of Internal Time, 1893-1917. Trans. John Barnett Brough. Norwell, MA: Kluwer. Kaye, Joel. 2000. Economics and Nature in the Fourteenth Century. Cambridge, UK: Cambridge University Press. 
Mill, John Stuart. 1963 (1844). "Essay V." Essays on Some Unsettled Questions on Political Economy, in Collected Works of John Stuart Mill, Vol. 4, ed. J. M. Robson. University of Toronto Press.

Pijanowski, Bryan C., Luis J. Villanueva-Rivera, Sarah L. Dumyahn, Almo Farina, Bernie L. Krause, Brian M. Napoletano, Stuart H. Gage and Nadia Pieretti. 2011. "Soundscape Ecology: The Science of Sound in the Landscape." BioScience, 61(3): 203-216.

Rose, Carol. 2003. "Romans, Roads, and Romantic Creators: Traditions of Public Property in the Information Age." Law and Contemporary Problems 66(89): 89-110.

Roughgarden, Jean. 2010. The Genial Gene: Deconstructing Darwinian Selfishness. Berkeley, CA: University of California Press.

Schafer, R. Murray. 2006. "I Have Never Seen a Sound." Environmental and Architectural Phenomenology Newsletter. Spring 2006. Accessed July 10, 2015 at http://www.arch.ksu.edu/seamon/Schafer06.htm

Schütz, Alfred. 1951. "Making Music Together: A Study in Social Relationship." Social Research 18 (1): 76-97.

Shapin, Steven. 1994. A Social History of Truth: Civility and Science in Seventeenth-Century England. Chicago, IL: University of Chicago Press. Smith, Adam. 1776. An Inquiry into the Nature and Causes of the Wealth of Nations. London: W. Strahan.

Smith, Julie A., and Robert W. Mitchell, eds. 2012. Experiencing Animal Minds. New York: Columbia University Press.

Thoreau, Henry David. 1971. Walden. Princeton: Princeton University Press. Press.

1981. Journal. Vol. 1: 1837-1844. Princeton: Princeton University

Press.

Titon, Jeff Todd. 1984. "Introduction: The Music-Culture as a World of Music." In Worlds of Music, ed. Jeff Todd Titon: 1-32. New York: Schirmer Books.

. 1996. "Knowing Fieldwork." In Shadows in the Field, ed. Gregory Barz and Tim Cooley: 87-100. New York: Oxford University Press. . 2001. Old-Time Kentucky Fiddle Tunes. Lexington, KY: University Press of Kentucky.

- 2008-present. Sustainable Music: a Research Blog. Accessed July 10, 2015 at http://sustainablemusic.blogspot.com 2012. "A Sound Commons for All Living Creatures." Smithsonian Folkways Magazine, Fall-Winter 2012. Accessed July 10, 2015 at http:// 
www.folkways.si.edu/magazine-fall-winter-2012-sound-commonsliving-creatures/science-and-nature-world/music/article/smithsonian 2015. "Sustainability, Resilience, and Adaptive Management for Applied Ethnomusicology." In The Oxford Handbook of Applied Ethnomusicology, eds. Svanibor Pettan and Jeff Todd Titon: 157-195. New York: Oxford University Press.

Wenner, Adrian M. 1964. "Sound Communication in Honey Bees." Scientific American 210: 116-124.

White, Gilbert. 2013 [1789]. The Natural History of Selborne. New York: Oxford University Press.

Worster, Donald. 1994a. Nature's Economy. $2^{\text {nd }}$ ed. Cambridge, UK: Cambridge University Press. 1994b. The Wealth of Nature: Environmental History and the Ecological Imagination. New York: Oxford University Press.

Zhao, Shanyang. 2012. "Toward a Taxonomy of Copresence." Presence 12: 445-455. 